\title{
Making the Implicit Explicit: Music Listening, Blended Delivery and the Representational Redescription Model
}

\author{
Patricia Boechler, Luis Fernando Marin, Brenda Dalen, Erik deJong \\ University of Alberta, Canada
}

\begin{abstract}
Close listening, perhaps the most important skill in music education is seldom practiced in the $21^{\text {st }}$ century. The ability to listen, understand, communicate, and interpret what you hear is central to education in general and transferable to many life situations and modes of communication. For this reason, listening is the primary focus of most first year post-secondary music history courses. It is also one of the most challenging skills to teach in large classroom formats. To address these challenges, we developed a blended delivery approach to support recognition, comprehension, and communication of musical materials. Based on the literature on music cognition and Karmiloff-Smith's (1992) Representational Redescription Model (RR Model) of knowledge acquisition, we designed a cognitive framework to support the design of enhanced listening models. This paper describes the results of a pilot project which presented the students with selfpaced on-line listening activities followed by a virtual listening/discussion session with peers. Both activities were well-received by the students and level of music experience was not associated with students' perceived value of the activities, indicating that students with varied backgrounds found the activities useful. The results support our cognitive framework as a foundation for technologicallyenhanced listening activities for postsecondary music courses.
\end{abstract}

\section{Introduction}

In our university undergraduate music history program we have identified four core competencies that are emphasized at various stages of the curriculum: listening, score reading, critical thinking, and communication. Generally, the sequencing of these competencies follows traditional pedagogical thought relating to the hierarchies of cognitive learning (particularly Bloom's Taxonomy), but lacks consideration of music's affective and procedural domains, arguably integral to the experience of music. Close listening is seldom practiced, and this skill is perhaps the most important feature in teaching music: the skill of listening is transferable to many life situations and modes of communication, and the ability to listen, understand, communicate, and critique or interpret what you hear is central to education in general, and not just to music. For this reason, listening is the primary focus of first year music history courses, for majors and general interest students. It is also one of the most challenging skills to teach to all but a small class of students. In teaching large classrooms of first year Music courses to non-majors with 50-400 students, for example, student learning often reflects a memorization of responses provided by the instructor more than it does the encouragement of independent listening skills that would lead to understanding and further application. Given the limited time allowed for faceto-face contact, the result is that very little music is even presented to students in the classroom. We believe that developing the skill of close listening not only improves student involvement in their own classroom learning, but ultimately also expands the transferability of listening skills beyond music courses, specifically when students are encouraged to communicate their own responses to the experience.

Large classrooms are particularly unfortunate places to learn about or even listen to music. The post-secondary semester system, with its fixed numbers of weeks and hours within them, offers very little time and space for face-to-face contact. And while listening, reading, and discussing are encouraged outside the classroom, without guidance these activities provide little advancement for students. We listen as individuals, but we respond to what we hear as a community. And the connections we make through music enhance our social place and space. In-class discussions rarely leave time for such reflection or feedback from others, and the subjectivity of musical critique leaves many students mute, afraid to speak about what they hear.

The primary challenges to teaching music history in post-secondary education are related to time, space, the extent of historical content needing to be covered, and the varied background of participants (i.e., musical training on entry in the program). These challenges exist in all mid- to large-sized classrooms and some smaller situations as well. The need to comprehend a great deal of specialized 
terminology, to develop adequate understanding of graphic notation, to not only understand but also to hear complex structural organization of sounds, and a general unfamiliarity (and lack of comfort) with expressing subjective responses are all barriers to success to many students for whom music is largely a background event.

Classroom learning of music history has traditionally involved listening (usually once) to short excerpts of longer music, an instructor pointing out 'what to listen for', and perhaps a brief lecture, reading, or discussion of how the music exemplifies some aspect of cultural history. While these traditional classroom processes meet with some success for students with previous formal music training, with the drastic reductions (even abolishment) of music education in elementary and secondary schools in North America, there is no longer any guarantee that students entering university are able to identify simple musical elements of rhythm, harmony, or form, let alone that they have training in theoretical and analytical practices or breadth of repertoire beyond a personal interest in popular cultures. These foundational features of music learning need to be mastered before more complex concepts are introduced and are therefore typically taught as a first step in postsecondary introductory music courses in order to bring students from varied backgrounds to a similar place of understanding and ability to communicate. For students wishing to gain an understanding of musical styles and cultural ideas in a range of music including 'classical', traditional, or popular cultures, specialized terminology, a breadth of cultural understanding, and close listening are therefore essential components of their education.

Beyond basic terminology, however, is the critical thinking required to connect unfamiliar and seemingly dissimilar cultural works - works of literature, visual art, and audio/video materials, for example. As our research discovers, the unevenness of prior musical experience that necessitated learning of foundational materials has little direct impact on this phase of learning; success at subsequent phases is dependent on the development of close listening (at a minimum, this involves an increased attention to musical materials) as well as explicit knowledge of the musical terminology needed to communicate what is heard.

In order for the researchers to understand the situation in these classrooms, we developed an entrylevel survey for all students in the course that asked specific questions regarding their prior experiences with music and dance. Questions included general experiences such as: "Do you sing, dance or play a musical instrument?" and "Have you taken formal training in dance or participated in community/cultural dancing?", as well as more technical concerns such as: "Can you sing or play 'by ear'?" and "Can you read musical notation?". Student responses to these questions were not known in advance of the preparation of materials for the project, but were found to be central to our interpretation of their work and in relation to an exit survey that asked (among other things) whether they felt that the activities were significant in improving their ability to listen.

The following points summarize the challenges faced in large size music courses:

1. Time:

a. insufficient time to listen fully to long selections or multiple selections

b. insufficient time for adequate discussion and feedback

2. Space:

a. distractions of competing sounds and movement within classrooms that interfere with students' ability to actual hear important features of the music

b. inferior audio equipment and recording techniques that compress the dynamic range of sounds, rendering important features of music practically inaudible

3. Varied background/experiences of participants:

a. basic understanding of the elements of music and of any one type of music cannot be assumed

b. an understanding of music in the context of other social and cultural domains is largely missing from all but the most specialized training.

4. Vastness of historical content:

a. due to time/space constraints, a few, select pieces of music become representative of the whole, leading to canonization and gaps in learning

b. a focus on one cultural field (in this case, music) isolates the object from the environment in which it was created and its relationship to other objects (a further place of learning and understanding) is ignored

To address some of the challenges of large, introductory music classes, we propose a blended delivery approach, where students spend one half of their course time in face-to-face activities in the classroom and the other half partaking in online activities that specifically target the listening process. There are numerous advantages to this approach: 1) having half the course material online frees up class time and allows the instructor to split a large class into smaller groups and thus to engage in more 
meaningful face-to-face activities, 2) the students move through instructional material online in a flipped classroom approach, exposing them to basic information and carefully designed activities to prepare them for a subsequent face-to-face classroom experience, 3) online technologies provide the opportunity for multi-modal presentations of information across cultural contexts, and 4) students are able to review supplementary and class materials and repeat activities as many times as it takes for them to understand. In order to provide a strong theoretical underpinning for our choices, we turned to the literature on music cognition.

\section{The cognition of listening}

When considering listening to music, rather than music production (playing an instrument or singing), there are smaller differences between novices and experts than might be expected. Scholars in the cognition of music such as Henkjan Honing (2009) contend that humans have an innate ability to hear regularity in music (the meter or beat of the music) as well as to recognize melody (relative pitch) [1]. Even newborn babies are sensitive to musical nuances within these two elements and can detect a missing beat or change in melody. At the same time, a melody can be altered in numerous ways and still be recognized, as long as it retains the relationship and sequences of the notes. This ability to hear a melody despite changes in how it is presented is referred to as "perceptual invariance".

Honing also contends that these innate abilities are strengthened as people listen to music over time and that accumulated experience represents implicit knowledge-i.e., knowledge that individuals are not aware they possess - of the conventions or regularities common in the music of their own culture. That is, people with no formal musical training often confuse their inability to produce music with an inability to hear: e.g., "I can't sing; I am tone-deaf". Given Honing's perspectives on the cognition of listening, it follows that the goals of music education, and thus of any listening activity we design should be to make explicit what is implicitly known. Our goals in this project were to look for ways to make students aware of their ability to detect musical nuances and to give them linguistic labels to enable them to share their listening experience with others as well as to apply this learning to more complex activities involving listening, reading, and witnessing of different forms of cultural expression.

\section{A cognitive framework for guided listening}

These goals align well with the concepts described in Karmiloff-Smith's Representational Redescription Model (RR Model) of knowledge acquisition [2]. The basic premise of the RR Model is that implicit knowledge (mental representations) gradually becomes explicit (sharable) knowledge through a process of four steps that she refers to as "redescription".

First, individuals acquiring new knowledge begin by holding some knowledge that they are unaware of but that is enabling them to respond to stimuli in their environment. Karmiloff-Smith refers to this as Implicit Level (I). In the case of our music students, this level would be evidenced by their ability to say yes or no to the question, "Did you hear a change?" after listening to two similar but not identical pieces of music even though they cannot say how they knew or what the specific change may be.

The second level, Explicit Level One (E1), furthers the process of redescription when the student begins to be aware of the specific part of the music that has actually changed. Again, in the case of our music students, this would be evidenced by answering the multiple choice question "Where does the change appear a) at the beginning, b) in the first half, c) in the second half, d) at the end?"

In the third level, Explicit Level Two (E2), the mental representations from $E 1$, become more clearly articulated and available to the individual in an evolved form. For our music students, this would mean being able to attach an auditory/verbal label to different aspects of the music heard. KarmiloffSmith explains that E2 representations most likely take a similar form to the original input, in this case, auditory input. As they move through these activities, students are given a verbal explanation that further articulates the changes they detected. For example, "The change you are detecting is a change in rhythm. Rhythm is defined as the grouping of beats into a recurring pattern as defined by accents." Through a sequence of listening to multiple pairs of pieces and being tutored on the terms used to describe the changes they are hearing, students begin to acquire linguistic labels that will help them differentiate these changes.

In our on-line listening activities, students will be scaffolded into Explicit Level Two (E2) through the process of verbal tutoring regarding their listening experience. Once the student has mastered the questions in Levels One and Two, they will be given examples that guide them to connect their knowledge of these materials to new and different material. For example, the activity might direct them to read an 
excerpt from literature and to discuss its expressive qualities, then follow this with a listening exercise that shares similar stylistic features, and ask students to describe what they hear in comparison to what they have read, thereby reinforcing learning and encouraging further connectivity across cultural objects and ways of knowing.

The fourth and final level, Explicit Level Three (E3), involves the highest level of redescription, where the individual has access to multiple forms of the evolved knowledge. For instance, students would now be presented with the written (visual) version of the terms they learned through the verbal tutoring. They may also see diagrams that explain further the nature of the terms and might even begin to pull these numerous forms together to start the process of score reading. This is also the level in which the sample pieces would be further contextualized within their historical space. Elements of music could, for example, be situated within the cultural milieu of the specific time and place of its creation. A sample statement here might be: "The [rhythm] you hear at the beginning of this music is very typical of [this country] and reflects the [folk songs] of that time." Students might then be asked to describe specific features of a dance video as they relate to unique cultural expression, for example. Karmiloff-Smith stresses the importance of the role of verbal interaction with others in furthering the redescription process during the $E 3$ level.

As a summary, based on the RR Model, the cognitive framework we are applying to the guided listening sections of our blended delivery course has four parts: 1) making implicit knowledge explicit for the individual through automatic responses, 2) behavioral mastery, 3) providing auditory cues to assist the listener in describing their knowledge in musical terms, and 4) promoting linguistic competency in using musical terms through multiple forms of the knowledge so students are able to communicate to and discuss their knowledge with others.

\subsection{Specific technologies to deliver the cognitive framework for guided listening}

3.1.1. Articulate Storyline. For each of our chosen applications, students will click on the appropriate icon embedded in a given module in the Learning Management System Moodle. We begin our guided listening activities at Implicit Level (I) using the software Articulate Storyline which allows for the creation of interactive presentations with quiz features and audio capacity (see Figure 1). Here we developed a series of listening activities that prompt students to tap into their innate knowledge and to simply detect difference $(I)$ and then to bring to awareness their knowledge (E1) so that they can elaborate on these differences. The goal in this activity is to give students practice in drawing on the implicit knowledge they already possess to detect whether a change has occurred in two pieces of music, to listen and identify musical elements. Articulate Storyline enables the instructor to create multiple auditory presentations of music pairs that allow students to listen to, respond, and receive new information, and then to listen again, respond, etc. until they are confident they can detect that a change has occurred between each piece in a musical pair. The advantages of this type of activity are that: 1) the activity is done independently, and with individual results so students can develop their listening skills without being inhibited by being observed, 2) students can complete the activities asynchronously, and 3) activities are repeatable until the student feels $\mathrm{s} / \mathrm{he}$ is beginning to hear changes in the music. Moodle would also be used to support the transitions expected in Explicit Level One (E1) where students would be faced with increasingly more difficult questions about what aspects of change they are hearing within the music pairs. For incorrect answers, students would receive feedback on their answers and suggestions for further listening in order to guide them to the correct answer.

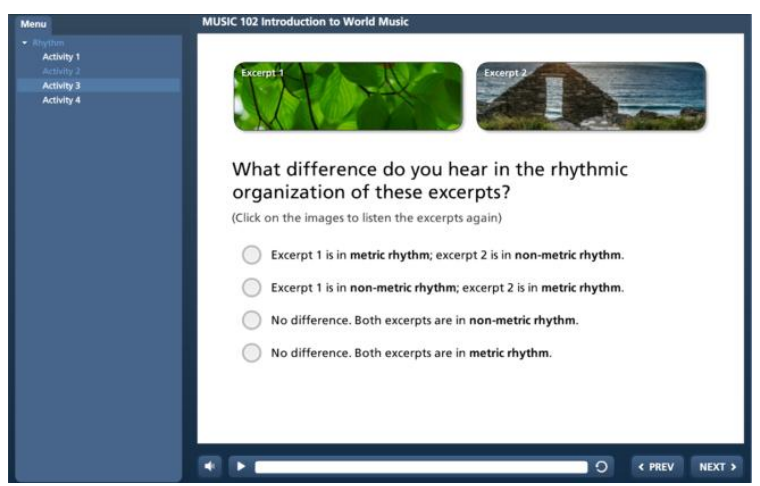

Figure 1. Sample of Articulate Storyline activity regarding the identification of musical elements: listen and answer questions on differences in melody, harmony, rhythm, timbre, and texture

3.1.2. Adobe Connect. Adobe Connect is a webconferencing system that allows for real time, synchronous verbal interaction between the instructor and students within the class. The advantages of synchronous interaction is that it: 1) encourages collaborative learning, thereby validating subjective responses through conversation between the instructor and the students, 2) assignments can also be set up for use asynchronously, 3) the software allows for the possibility of providing 
additional (to E2) and varied modes of explanation for difficult terminology and foundational elements such as using visual, aural, and verbal cues to assist with understanding simple and complex rhythm and meters, major and minor harmonic modes, and in reading basic musical notation-e.g., 'click to play' options, highlighting of important features or patterns, pointing to graphic images, etc. might be provided for reference (see Figure 2). The Adobe Connect session allows the instructor to present more complex material and terms and to answer students' questions immediately. The goal of these activities might be primarily to listen and discuss features of musical style. During these sessions, students would be given a series of questions of an increasingly subjective nature in an instructor-guided conference environment (Adobe Connect) that enhances E2 learning. Guided questions would lead students to a final question on describing some of the musical features of a specific style period based on selected music, images, and texts from that period. Such activities help students to connect musical terms and concepts to the knowledge that they now are aware they possess.

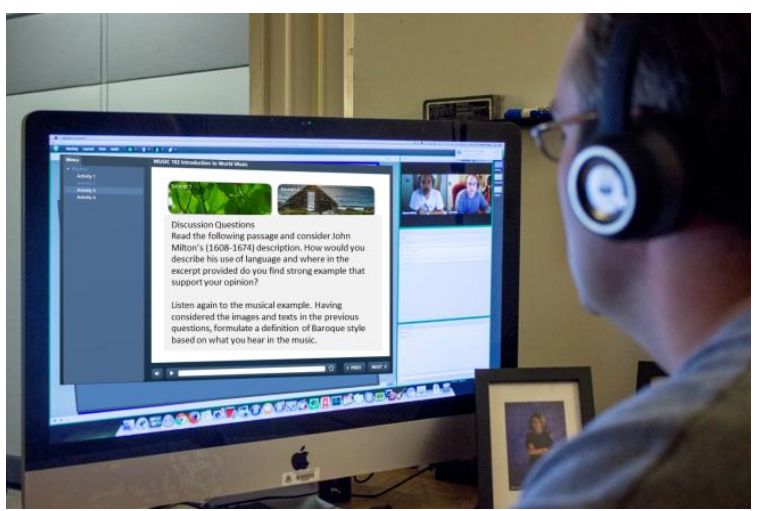

Figure 2. Sample of Adobe Connect activity designed to assist students in hearing distinct musical styles: listen and discuss features of musical styles

3.1.3. OpenSim. OpenSim is an open source version of Second Life, an avatar-based, immersive virtual world where every avatar is a student interacting with another student in real time. OpenSim allows for the presentation of interactive multimedia material (e.g., powerpoints, videos, websites etc.) that can be controlled by the students themselves in a collaborative session without the instructor present. The added advantage of OpenSim over Adobe Connect is that students interact with each other through their avatar, which is reported to enhance their sense of themselves as present in the discussion environment and their sense of the presence of other students as well [3]. This technology allows a sophisticated creative space for students to interact with multiple modes and artifacts in order to consider music's relationship to other arts and cultures and to link multiple modes of cultural expression to their understanding of a particular time, place, or style of music. The advantages are that: 1) like Adobe Connect, it is used synchronously and therefore encourages social interaction, 2) it allows for shared creation of projects or responses, 3 ) it models collaborative learning in a more immersed setting that might be further experienced in face-toface situations, and 4) it requires complex (self-) critique of cultural learning (metacognition) in which every decision requires individuals to consider the appropriateness and effectiveness of their choices within a larger community and context of learning. Activities within OpenSim include group listening tasks and group discussions in response to questions provided, with a final summary, using appropriate musical terms, to describe the nuances heard in musical selections (see Figure 3).

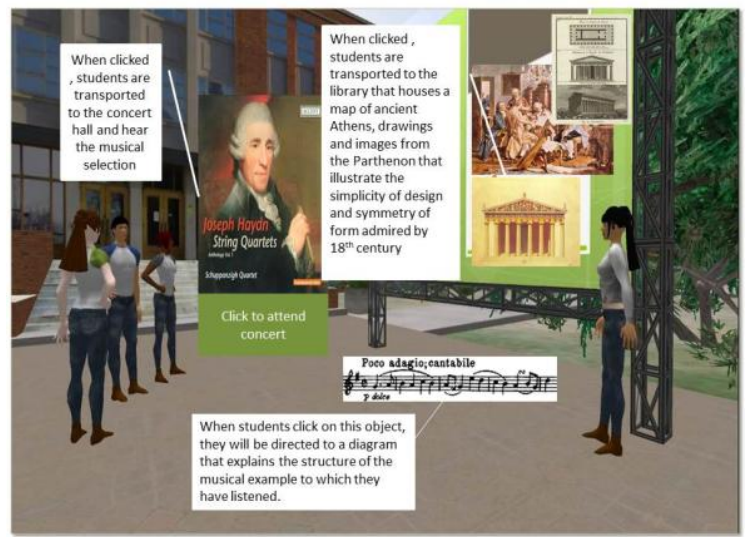

Figure 3. Sample of OpenSim activity asking students to describe cultural context: listen and synthesize

Through these activities, students learn to listen and synthesize. By immersing them in the context in which the music was created, students also will better understand the influences on and impacts of its creation. For example, in the virtual environment illustrated in Figure 3, students are invited to discover/click on objects relating to a specific piece of music (here, a Haydn string quartet), experience that activity (listen to the music, read an excerpt, watch a video), and then to consider each object in the space as a clue to understanding the social and cultural contexts of its composition (e.g., in Figure 3, to consider the influence of Classical architecture and literature on musical style in the late $18^{\text {th }}$ century), and to participate in directed discussion by 
responding to general questions provided in the environment along with each object.

\section{Methods}

The research on this delivery method is correlational, investigating the relationships between traits and prior experience of students to their levels of satisfaction and perceptions of their learning. Our pilot conducted in Fall 2014 included the Articulate listening activities (which we refer to as on-line listening) and the OpenSim discussion activities (which we refer to as virtual discussions). The online listening was implemented at the end of October, followed by the virtual discussions at the end of November, beginning of December.

Before the listening activities commenced, general demographics were collected (e.g., program, year in program, gender, age). Students also completed: 1) a music experience survey (non-credit music experience, see Appendix A), 2) a selfregulation questionnaire (SRQ) [4], and 3) a Computer Experience Questionnaire [5].

The Self-regulation Questionnaire contains 63 items on a 5 point likert scale. Items are both positive and negative statements such as "I usually keep track of my progress toward my goals" and "I get easily distracted from my plans". The higher the score, the higher the student's level of self-regulation.

The Computer Experience Questionnaire is comprised of three measures: 1) the Software Recognition Test, which is a measure of general exposure to computer applications and digital materials, 2) the Educational Activities Checklist (EAC) which is the number of education-related computer activities students have carried out (e.g., writing html code, using a formula in a spreadsheet, using a library database), and 3) the Recreational Experience Scale (RES) which is the number of hours per week students spent playing video games or social networking in Elementary, Junior High, High School and University. We used a total computer experience aggregated score in our analyses.

At the end of the course, students completed a student perception of value survey (e.g., their own listening ability/learning and satisfaction with listening activities) (see Appendix B).

We addressed the following research questions in this pilot.

1) Does prior music or computer experience predict the students' perceived value (PV) of the on-line listening activities?
2) Does age or the degree of self-regulation skill predict the students' perceived value of the on-line listening activities?

3) Is there a correlation between prior music experience, computer experience, degree of self-regulation and the students'perceived value of the virtual discussions?

\section{Results}

As a larger number of students completed the on-line listening activities ( $n=66$ ), we had a large enough sample to conduct regression analyses for the first two research questions.

The descriptive statistics for the $n=66$ sample appear in Table 1 . The perceived value survey for the on-line listening activities had a maximum score of 60. Given the mean score was 44 , it appears the activities were generally well-received by the students.

Table 1. Mean and standard deviation for all variables of $n=66$ sample.

\begin{tabular}{lll}
$\mathrm{n}=66$ & $\mathrm{M}$ & $\mathrm{SD}$ \\
\hline Age & 20.17 & 3.92 \\
Music Exp & 4.80 & 1.83 \\
Computer Exp & 26.09 & 6.67 \\
Self-regulation Score & 213.55 & 13.42 \\
PV On-line Listening & 43.59 & 8.96 \\
\hline
\end{tabular}

The first regression analysis represents the influence of prior experience variables (music experience and computer experience) on the perception of value of the on-line listening activities (see Table 2). The analysis indicates neither prior music experience nor prior computer experience predicted students' perceived value of the activities.

Table 2. Multiple regression analysis for the music experience and computer experience on the perceived value of the on-line listening activities, $\mathrm{n}=66$.

\begin{tabular}{|l|l|l|l|l|l|}
\hline Variables & $B$ & $S E B$ & $\beta$ & $t$ & Sig \\
\hline Music Exp & -.739 & .609 & -.151 & -1.21 & .230 \\
\hline $\begin{array}{l}\text { Computer } \\
\text { Exp }\end{array}$ & -.001 & .167 & -.001 & -.004 & .997 \\
\hline
\end{tabular}


The second regression analysis represents the influence of age or level of self-regulation on the students' perceived value of the on-line listening activities (see Table 3).

Table 3. Multiple regression analysis for age and self-regulation scores on the perceived value of the on-line listening activities, $\mathbf{n}=$ 66.

\begin{tabular}{|l|l|l|l|l|l|}
\hline Variables & $B$ & $S E B$ & $\beta$ & $t$ & Sig \\
\hline Age & .782 & .269 & .343 & 2.90 & $.005^{*}$ \\
\hline $\begin{array}{l}\text { Self- } \\
\text { regulation }\end{array}$ & -.105 & .079 & -.157 & -1.33 & .188 \\
\hline
\end{tabular}

Although we might expect self-regulation skills to increase with age, the regression analysis indicated that, although age predicted the students' perceived value of the on-line listening activities, self-regulation level did not. The older students were, the more they valued the on-line listening activities.

For the third research question, we had 29 students respond to questions about the virtual discussions. The descriptive statistics for the $n=29$ sample appear in Table 4. The perceived value survey for the virtual discussions had a maximum score of 40 . Given the mean score was 31 , it appears the virtual activities were generally well-received by the students.

Table 4. Mean and standard deviation for all variables of $n=29$ sample.

\begin{tabular}{|l|l|l|}
\hline $\mathrm{n}=29$ & $\mathrm{M}$ & $\mathrm{SD}$ \\
\hline Age & 20.62 & 4.97 \\
\hline Music Exp & 4.31 & 1.92 \\
\hline Computer Exp & 25.83 & 7.15 \\
\hline Self-regulation Score & 214.66 & 12.88 \\
\hline $\begin{array}{l}\text { PV-Virtual } \\
\text { Discussions }\end{array}$ & 31.21 & 6.03 \\
\hline
\end{tabular}

Finally, we conducted a correlation analysis to detect any significant associations between prior music experience, computer experience, degree of self-regulation and the students' perceived value of the virtual discussions (see Table 5).
Table 5. Correlations between age, prior experience, self-regulation and perceived value of the virtual discussions

\begin{tabular}{|l|l|l|l|l|l|}
\hline $\mathrm{n}=29$ & Age & $\begin{array}{l}\text { Music } \\
\text { Exp }\end{array}$ & $\begin{array}{l}\text { Comput } \\
\text { Exp }\end{array}$ & $\begin{array}{l}\text { Self- } \\
\text { regulation } \\
\text { Score }\end{array}$ & $\begin{array}{l}\text { Virtual } \\
\text { Discuss } \\
\text { Score }\end{array}$ \\
\hline Age & 1 & -.296 & $-.443^{*}$ & .182 & .330 \\
\hline $\begin{array}{l}\text { Music } \\
\text { Exp }\end{array}$ & -.296 & 1 & .056 & -.158 & -.079 \\
\hline $\begin{array}{l}\text { Comp } \\
\text { Exp }\end{array}$ & $-.443^{*}$ & .056 & 1 & $-.374^{*}$ & .071 \\
\hline $\begin{array}{l}\text { Self-reg } \\
\text { Score }\end{array}$ & .182 & -.158 & $-.374^{*}$ & 1 & .149 \\
\hline $\begin{array}{l}\text { Virtual } \\
\text { Discuss } \\
\text { Score }\end{array}$ & .330 & -.079 & .071 & .149 & 1 \\
\hline * Correlation is significant at the 0.05 level (2-tailed). \\
\hline
\end{tabular}

The correlation analysis shows that none of the student variables that were measured at the outset of the study were significantly associated with the students' perceived value of the virtual discussions.

\section{Discussion}

This pilot study investigated the reactions of students to a technologically-enhanced postsecondary music course.

We focused on three research questions concerning students' abilities and traits that might influence their perceptions of the on-line course activities.

1) Does prior music or computer experience predict the students' perceived value (PV) of the on-line listening activities?

2) Does age or the degree of self-regulation skill predict the students' perceived value of the on-line listening activities?

3) Is there a correlation between prior music experience, computer experience, degree of self-regulation and the students'perceived value of the virtual discussions?

The results of our multiple regression and correlational analyses suggest that, for music students engaged in on-line listening activities and discussions about music, their prior music and computer experiences did not enhance nor detract from their experience of the on-line and virtual activities. In large introductory courses with students with very diverse histories and skills this is encouraging, as it would seem these activities will be 
executable by the majority of students and students with less experience will not be disadvantaged.

The only variable which predicted the students' perceived value of the on-line listening activities was age. As mentioned, this is not due to increased selfregulation capabilities as students mature because self-regulation skills themselves did not predict perceived value. Perhaps with increased maturity comes a more positive outlook on educational activities in general.

Regarding the perceived value of the virtual discussions, none of the pre-measured variables were associated with the survey outcomes. However, computer experience was significantly associated with self-regulations skills and age. Interestingly, this was a negative association for both, meaning that as age and self-regulation increased the scores on the computer experience questionnaire decreased and vice versa. This suggests that, in our sample, younger students had, or at least reported, higher computer skills than older students. As well, the higher the self-regulation scores, the lower the computer experience scores. This is difficult to interpret but may be due to those with high selfregulation scores being more apt to attend to other non-computer related tasks that are more goal-related for them.

\section{Conclusion}

Large introductory music courses present unique challenges to instructors, given the need to help students to develop listening skills in sub-optimal classroom conditions. Introducing technology to enhance any learning experience requires a careful analysis of learning goals and objectives, along with a careful choice of activities to elicit the intended learning. As a foundation for making such choices in a music course, we have described the underlying cognition of listening and a cognitive framework based on Karmiloff-Smith's Representational Redescription Model (RR Model) of knowledge acquisition. We used these to design the guided listening activities that assisted students in developing the critical skills of listening and sharing their subjective understandings of the music they hear. Our pilot study suggests that such activities show promise for enhancing post-secondary music courses without disadvantaging students with lesser music experience. In fact, our results indicate that the impact of the on-line listening activities prepares all students equally for the subsequent technologyenhanced listening activities and provides the scaffolding from implicit to explicit knowledge that we designed for using the Representational Redescription Model (RR Model).

\section{References}

[1] H. Honing, Musical Cognition: The Science of Listening. Transaction Publishers, Rutgers, NJ, 2009.

[2] A. Karmiloff-Smith, Beyond Modularity: A Developmental Perspective on Cognitive Science. MIT Press, Cambridge, MA, 1992.

[3] R. McKerlich, T. Anderson, M. Riis, and B. Eastman, "Student Perceptions of Teaching Presence, Social Presence and Cognitive Presence in a Virtual World", Journal of Online Learning and Teaching, 2011, 7, 3.

[4] J.M. Brown, W.R. Miller, and L.A. Lawendowski, "The Self-Regulation Questionnaire," in L. VandeCreek and T. L. Jackson (Eds.), Innovations in Clinical Practice: A Source Book, Vol. 17, Professional Resource Press, Sarasota, FL,1999, , pp. 281-289.

[5] P. Boechler, L. Leenaars, and I. Levner, "Recreational vs. Educational Computer Experience: Predicting Explicit and Implicit Learning Outcomes During a Website Search", in K. McFerrin et al. (Eds.), Proceedings of Society for Information Technology \& Teacher Education International Conference, AACE, Chesapeake, VA, 2008, pp. 2499-2501. 


\section{Appendix A}

\section{Pre survey - Music 102}

Name:

Age:

Year in program: 1

$2 \quad 3$

$4 \quad 5$

Program: BA

BMus

$\mathrm{BSc}$ $\operatorname{BEd}$

Have you ever taken a course in (check all that apply):

music theory

music history

popular music

Please answer the following questions.

\begin{tabular}{|c|c|c|}
\hline & Yes & No \\
\hline 1. Do you sing, dance, or play a musical instrument? & & \\
\hline $\begin{array}{l}\text { 2. Have you ever sung in a choir or played in a band or } \\
\text { orchestra? }\end{array}$ & & \\
\hline $\begin{array}{l}\text { 3. Have you taken formal training in dance or } \\
\text { participated in community/cultural dancing? }\end{array}$ & & \\
\hline 4. Can you sing or play "by ear"? & & \\
\hline 5. Can you read musical notation? & & \\
\hline 6.Do you have any previous knowledge of world music? & & \\
\hline
\end{tabular}


Appendix B - Final Perceived Value Survey

\section{Final Music 102 Survey}

Name

Your name will not appear in any publication, and you are free to not participate at all, or stop participating if you wish, at any time.

Please rate the statements below from 1-5.

\begin{tabular}{|c|c|c|c|c|c|}
\hline $\begin{array}{l}\text { ON-LINE LISTENING } \\
\text { ACTIVITIES }\end{array}$ & $\begin{array}{l}\text { Strongly } \\
\text { disagree }\end{array}$ & Disagree & Neutral & Agree & $\begin{array}{l}\text { Strongly } \\
\text { Agree }\end{array}$ \\
\hline & 1 & 2 & 3 & 4 & 5 \\
\hline $\begin{array}{l}\text { I found the on-line listening } \\
\text { activities easy to use. }\end{array}$ & & & & & \\
\hline $\begin{array}{l}\text { I enjoyed the on-line listening } \\
\text { activities. }\end{array}$ & & & & & \\
\hline $\begin{array}{l}\text { I listened to the music } \\
\text { selections more than once. }\end{array}$ & & & & & \\
\hline $\begin{array}{l}\text { I found the multiple choice } \\
\text { questions were clear. }\end{array}$ & & & & & \\
\hline $\begin{array}{l}\text { I feel the on-line listening } \\
\text { activities helped me increase } \\
\text { my ability to hear musical } \\
\text { elements. }\end{array}$ & & & & & \\
\hline $\begin{array}{l}\text { I feel the on-line listening } \\
\text { activities helped me increase } \\
\text { my ability to identify musical } \\
\text { elements. }\end{array}$ & & & & & \\
\hline $\begin{array}{l}\text { I feel the on-line listening } \\
\text { activities helped me improve } \\
\text { my understanding of different } \\
\text { musical styles. }\end{array}$ & & & & & \\
\hline $\begin{array}{l}\text { I think the on-line listening } \\
\text { activities were worthwhile } \\
\text { activities in the course }\end{array}$ & & & & & \\
\hline $\begin{array}{l}\text { I would engage in more of the } \\
\text { on-line listening activities if } \\
\text { they had been available in the } \\
\text { course. }\end{array}$ & & & & & \\
\hline $\begin{array}{l}\text { The on-line listening activities } \\
\text { were helpful for students with } \\
\text { no experience in music. }\end{array}$ & & & & & \\
\hline $\begin{array}{l}\text { The on-line listening activities } \\
\text { were helpful for students with } \\
\text { a lot of experience in music. }\end{array}$ & & & & & \\
\hline $\begin{array}{l}\text { I would recommend to a } \\
\text { friend that he/she complete the } \\
\text { on-line listening activities }\end{array}$ & & & & & \\
\hline $\begin{array}{ll}\text { VIRTUAL } & \text { WORLD } \\
\text { SESSIONS } & \end{array}$ & $\begin{array}{l}\text { Strongly } \\
\text { disagree }\end{array}$ & Disagree & Neutral & Agree & $\begin{array}{l}\text { Strongly } \\
\text { Agree }\end{array}$ \\
\hline
\end{tabular}




\begin{tabular}{|l|l|l|l|l|l|}
\hline & 1 & 2 & 3 & 4 & 5 \\
\hline $\begin{array}{l}\text { I found it easy to use my } \\
\text { avatar in the virtual world } \\
\text { discussions. }\end{array}$ & & & & & \\
\hline $\begin{array}{l}\text { I was not hesitant to speak up } \\
\text { in the virtual world } \\
\text { discussions. }\end{array}$ & & & & \\
\hline $\begin{array}{l}\text { I felt uncomfortable in the } \\
\text { virtual world discussions. }\end{array}$ & & & & \\
\hline $\begin{array}{l}\text { The virtual world discussions } \\
\text { were enjoyable. }\end{array}$ & & & & \\
\hline $\begin{array}{l}\text { The microphone was easy to } \\
\text { use in virtual world } \\
\text { discussions. }\end{array}$ & & & & \\
\hline $\begin{array}{l}\text { The virtual world discussions } \\
\text { helped me understand the } \\
\text { background to specific music } \\
\text { styles. }\end{array}$ & & & & \\
\hline $\begin{array}{l}\text { I think the virtual world } \\
\text { discussions were a worthwhile } \\
\text { activity in the course. }\end{array}$ & & & & \\
\hline $\begin{array}{l}\text { I would recommend to a } \\
\text { friend that he/she complete the } \\
\text { virtual world discussions } \\
\text { activity. }\end{array}$ & & & & & \\
\hline $\begin{array}{l}\text { I would engage in more of the } \\
\text { virtual discussion activities if } \\
\text { they had been available in the } \\
\text { course. }\end{array}$ & & & & \\
\hline
\end{tabular}

